\title{
PENGARUH MUTASI DAN BUDAYA ORGANISASI TERHADAP KEPUASAN KERJA DI LINGKUNGAN PT PEGADAIAN (PERSERO)
}

\author{
Sedarmayanti \\ Gun Gun Gunawan
}

\begin{abstract}
Dosen Prodi Magister Manajemen, Universitas Kristen Maranatha Alumni Prodi Magister Manajemen Universitas Kristen Maranatha

Email: sedarmayanti@gmail.com; gun2awan@gmail.com
\end{abstract}

Submitted: Feb 1, 2019; Reviewed: Feb 2, 2019; Accepted: Apr 3, 2019

\begin{abstract}
This study using data analysis methods namely multiple regression models that are used to see the effect of independent variables, namely Mutations (X1) and Organizational Culture (X2) on the dependent variable, namely Job Satisfaction $(Y)$, so that in research this aims to be able to produce data processing that has been done at PT Pegadaian (Persero) Kanwil X Bandung, then tested using the T test and $F$ test, showing that mutation variables and organizational culture simultaneously on job satisfaction shows results as complete as $53.8 \%$ or has a Sig. value of 0.000 where this value is smaller than the significance level used is 0.05 , which means that $\mathrm{HO}$ is rejected while for partial mutation variables for the variable job satisfaction of $27.04 \%$ or having a Sig. value of 0.011 is smaller than 0.05 , meaning $\mathrm{HO}$ is rejected so that it only has $1.1 \%$ and variables organizational culture on job satisfaction is $51.27 \%$ or has a Sig. value of 0.000 smaller than 0.05 , which means that HO is rejected so that it only has an effect of $0 \%$ where all of these variables produce a continuum in the good category based on responses from employees as respondents from filling the questionnaire.
\end{abstract}

Keywords: Job Satisfaction; Mutations; Organizational Culture; PT Pegadaian (Persero)

\section{PENDAHULUAN}

PT Pegadaian (Persero) merupakan salah satu perusahaan yang bergerak di bidang jasa keuangan non perbankan milik BUMN (Badan Usaha Milik Negara) dengan fokus utama pekerjaannya yakni melayani jasa gadai dan pengajuan kredit usaha mikro. Pegadaian merupakan perusahaan jasa gadai terbesar di Indonesia yang sudah membuka kantor cabang/ outlet di seluruh wilayah Indonesia mulai dari Sabang sampai Merauke. Dengan sistem penerapan kepegawaian PKWT (Perjanjian Kerja Waktu Tertentu) dan PKWTT (Perjanjian Kerja Waktu Tidak Tertentu).

Pada dasarnya pegawai yang bekerja di pegadaian sebagian besar dihuni perantauan bukan oleh putra-putri daerah yang biasanya dilakukan oleh perusahaan-perusahaan keuangan lainnya seperti perbankan. Pegawai tersebut pada saat menerima SK (Surat Keputusan) Direksi Pengangkatan Pegawai di tahun pertama, umumnya ditempatkan di daerah-daerah kecil di Indonesia yang tingkat konsumsi gadainya tinggi namun kekurangan jumlah pegawai. Dalam hal ini putra daerah terkadang tidak tertarik bekerja di pegadaian dikarenakan kurang bersaingnya penampilan dibandingkan dengan bekerja di perusahaan sekelas perbankan.

Namun, permasalahan baru timbul pada saat pegawai tersebut telah memasuki tahun kedua masa kerjanya, permasalahan tersebut antara lain adalah munculnya keinginan dari pegawai itu sendiri untuk dapat bekerja atau pindah ke kantor cabang terdekat dengan domisilinya masingmasing. Keinginan tersebut sebenarnya bukanlah hal yang penting maupun mendesak, tetapi dengan bekerja berada di daerah yang telah dianggap terkuasai, baik budaya maupun lingkungan akan mudah menciptakan suasana kerja yang lebih nyaman dan produktif. Keinginan perpindahan tersebut biasanya dituangkan sebagai 
permohonan dalam bentuk surat permintaan mutasi pegawai.

Proses yang sistematis dan terus menerus dalam menganalisis kebutuhan organisasi akan sumber daya manusia dalam kondisi yang selalu berubah dan mengembangkan kebijakan personalia yang sesuai dengan rencana jangka panjang organisasi. Hal ini merupakan bagian yang terintegral dari perencanaan dan anggaran perusahaan, karena pembiayaan dan perkiraan sumber daya manusia akan berpengaruh dan dipengaruhi oleh rencana jangka panjang perusahaan.

Salah satu faktor yang menjadi penentu berkembangnya sebuah organisasi atau perusahaan, tergantung dari sumber daya manusia dan budaya organisasinya. Organisasi seharusnya dapat menghargai bakat dan kemampuan para pegawai tersebut agar dapat diarahkan sesuai dengan keahlian dan minatnya, sehingga penempatan posisi pada organisasi atau perusahaan tersebut akan dapat berkembang dengan baik dan cepat, karena perusahaan yang berkembang dengan baik berarti dapat mengarahkan pegawainya melalui para pemimpin organisasinya yang memiliki kompetensi sehingga para bawahannya dapat bekerja lebih efisien dan seefektif mungkin. Budaya organisasi memberi ketegasan dan mencerminkan spesifikasi suatu organisasi sehingga berbeda dengan organisasi lain.

Perilaku pegawai merupakan hal yang penting dalam perusahaan-perusahaan jasa seperti bank dan perusahaan lainnya. Sumber daya manusia memainkan peran penting dalam perusahaan jasa. Keterampilan dan keahlian dari para pegawai dalam berorganisasi menjadi kunci keberhasilan dalam menciptakan peluang tercapainya tujuan, untuk itu organisasi harus mampu mengembangkan para pegawainya melalui sistem mutasi. Mutasi sebenarnya sudah dikenal oleh sebagian besar pegawai, di mana kata mutasi yang berarti pemindahan adalah kegiatan memindahkan pegawai dari satu pekerjaan lain yang dianggap setingkat atau sejajar dan juga pemindahan pegawai dari satu lokasi cabang ke kantor cabang lainnya, baik bertujuan sebagai penyegaran maupun penyesuaian formasi pegawai di kantor cabang tersebut. Mutasi merupakan suatu kegiatan yang dilakukan guna melaksanakan prinsip the right man in the right place atau (orang tepat pada tempatnya).

Mutasi sebenarnya diperlukan oleh pegawai dalam rangka meningkatkan dan memberikan keterampilan baru serta suasana 104 baru, di mana suasana atau lingkungan kerja yang nyaman akan sangat berpengaruh terhadap tingkat kualitas kerja dan terkadang dapat menimbulkan kepuasan tersendiri bagi pegawai tersebut, serta untuk mengurangi rasa kejenuhan akibat terlalu lamanya pegawai itu berada dalam satu tempat yang sama. Mutasi juga dapat dijadikan sebagai alat motivasi bagi pegawai agar dapat bekerja lebih baik lagi, mutasi tidak hanya berpengaruh terhadap posisi lokasi kerja, tapi dapat juga dilakukan sebagai penghargaan atas prestasi kerja pegawai tersebut, di mana pegawai itu meminta permohonan mutasi kerja untuk dipindahkan posisinya ke kantor cabang yang diinginkan agar kualitas kerja dan kepuasan kerja pegawai dapat tercapai di mana hal tersebut berpengaruh terhadap kecepatan tercapainya tujuan perusahaan. Bertitik tolak dari pernyataan di atas, bukan hanya mutasi pegawai yang mempengaruhi kepuasan kerja, namun budaya organisasi juga menjadi hal yang diperlukan untuk mendapatkan kepuasan kerja di dalam lingkungan perusahaan.

\section{RUMUSAN MASALAH}

Berdasarkan uraian di atas, maka beberapa masalah yang akan diteliti dapat dirumuskan sebagai berikut:

1. Apakah terdapat pengaruh mutasi secara parsial terhadap kepuasan kerja di lingkungan PT Pegadaian (Persero)?

2. Apakah terdapat pengaruh budaya organisasi secara parsial terhadap kepuasan kerja di lingkungan PT Pegadaian (Persero)?

3. Apakah benar terdapat pengaruh mutasi dan budaya organisasi secara simultan terhadap kepuasan kerja di lingkungan PT Pegadaian (Persero)?

\section{TUJUAN PENELITIAN}

Sesuai dengan rumusan masalah yang diajukan, maka tujuan penelitian ini adalah untuk mengukur dan menganalisis:

1. Pengaruh mutasi secara parsial terhadap kepuasan kerja di lingkungan PT Pegadaian (Persero).

2. Pengaruh budaya organisasi secara parsial terhadap kepuasan kerja di lingkungan PT Pegadaian (Persero).

3. Pengaruh mutasi dan budaya organisasi secara simultan terhadap kepuasan kerja di lingkungan PT Pegadaian (Persero).

\section{TINJAUAN PUSTAKA}

Penelitian ini memakai dasar penelitian terdahulu dari jurnal yang ditulis oleh Fadilah, Hakim, dan 
Siswidiyanto (2010:847-852) sebagai jurnal acuan pertama, di samping jurnal-jurnal yang lain sebagai jurnal pendukung. Dari beberapa jurnal tersebut diperoleh hasil yang berbeda-beda. Penelitian Fadilah et.al. (2010:851) dengan judul "Pengaruh penempatan karyawan terhadap kinerja" dalam kesimpulannya menjelaskan:

“...dengan nilai signifikansi dari uji $\mathrm{F}$ sebesar 0.000 dengan $\alpha$ (alpha) yang digunakan dalam penelitian ini sebesar 0.05 sehingga signifikansi (Sig.) $0.000<0.05$. Uji parsial t (sendiri-sendiri) juga menunjukkan bahwa variabel kesesuaian pengetahuan, kesesuaian kemampuan, dan kesesuaian keahlian masing-masing berpengaruh signifikan terhadap kinerja pegawai, hal itu ditunjukkan dengan nilai signifikansi masingmasing variabel dari uji t sebesar 0.000 dengan $\alpha$ (alpha) yang digunakan dalam penelitian ini sebesar 0.05 sehingga signifikansi (Sig.) 0.000 $<0.05$ ".

Sedangkan untuk jurnal acuan kedua menggunakan hasil penelitian dari Hormati (2016:298-310), di mana hasil dari penelitian tersebut menghasilkan kesimpulan penutup yang diantaranya:

"Budaya organisasi dan rotasi kerja berkonstribusi secara simultan signifikan terhadap motivasi kerja dan motivasi kerja secara parsial memiliki pengaruh positif signifikan terhadap kinerja pegawai".

Untuk meningkatkan kinerja pegawai, dapat dilakukan melalui rotasi pekerjaan, secara berkala dan terencana, dengan mempertimbangkan kesesuaian antara kemampuan dan keterampilan pegawai dengan pekerjaan yang baru.

\section{HIPOTESIS PENELITIAN}

Hipotesis dalam penelitian ini adalah:

H1: Terdapat pengaruh langsung antara mutasi dan budaya organisasi terhadap kepuasan kerja secara simultan.

$\mathrm{H} 2$ : Terdapat pengaruh langsung mutasi secara parsial terhadap kepuasan kerja.

H3: Terdapat pengaruh langsung budaya organisasi secara parsial terhadap kepuasan kerja.

\section{MODEL PENELITIAN}

Selanjutnya dapat digambarkan kerangka pemikiran menggunakan indikator-indikator sebagai berikut:

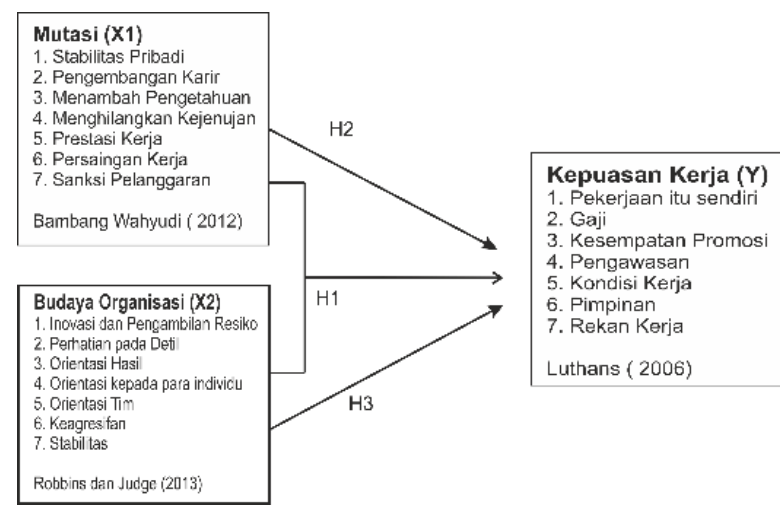

Gambar 1 Kerangka Pemikiran

Model penelitian ini merupakan abstraksi dari fenomena-fenomena yang sedang diteliti. Sesuai dengan judul yang penulis kemukakan, pengaruh mutasi dan budaya organisasi terhadap kepuasan kerja, maka secara sistematis untuk menggambarkan hubungan antara variabel independen dengan variabel dependen, penulis dapat memberikan model penelitian yang dinyatakan dengan fungsi sebagai berikut:

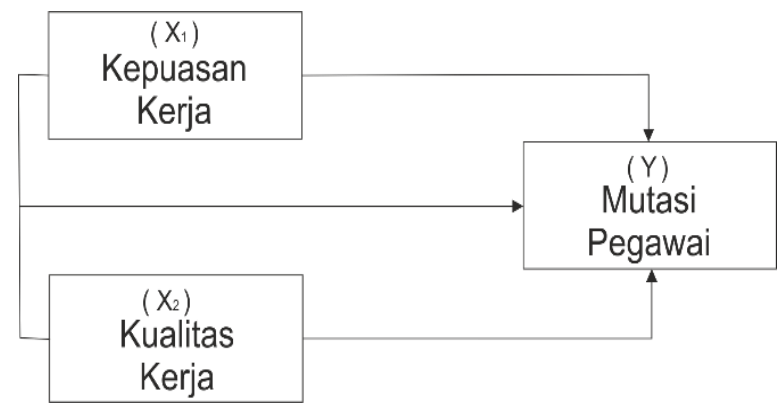

Gambar 2 Model Hipotesis Penelitian

Sumber: Modifikasi dari Jurnal Wibowo

(2014:4)

\section{POPULASI}

Menurut Sugiyono (2016:80), populasi adalah wilayah generalisasi terdiri atas obyek/subyek yang mempunyai kualitas dan karakteristik tertentu yang ditetapkan oleh peneliti untuk dipelajari dan kemudian ditarik kesimpulan. Populasi dalam penelitian ini adalah seluruh pegawai PT Pegadaian (Persero) Kanwil X Bandung sebanyak 550 orang.

Sampel yang digunakan dalam penelitian ini diambil dari populasi di PT. Pegadaian (Persero) Kanwil X Bandung dengan jumlah sampel yang dianggap sudah mewakili/ 
representative dari populasi yang ada. Untuk menghitung sampel rumus yang digunakan dalam penelitian ini adalah rumus Slovin, berikut rumus Slovin:

$$
\mathrm{n}=\frac{\mathrm{N}}{1+N e^{2}}
$$

Keterangan:

n: Jumlah sampel

$\mathrm{N}$ : Jumlah populasi

e: Persen kelonggaran ketidak telitian kesalahan pengambilan sampel yang dapat ditolerir (e dalam penelitian ini ditentukan sebesar 10\%)

Berdasarkan rumus tersebut dengan populasi 550 pegawai di PT Pegadaian (Persero) Kanwil X Bandung, maka ukuran sampel dapat dihitung sebagai berikut:

$$
\begin{gathered}
n=\frac{N}{1+N e^{2}} \\
n=\frac{550}{1+(550)(10 \%)^{2}} \\
=84.6 \text { dibulatkan menjadi } 85
\end{gathered}
$$

Jumlah sampel untuk penelitian ini adalah sebanyak 85 responden, hal tersebut dikarenakan adanya pembulatan bilangan.

Dalam penelitian ini teknik sampling yang digunakan yaitu Non Probability Sampling dengan teknik purposive sampling. Menurut Sugiyono (2016:85) purposive sampling adalah teknik pengambilan sampel sumber data dengan pertimbangan tertentu.

Dari jumlah populasi sebanyak 550 dan diambil sampel dengan rumus Slovin dengan jumlah sampel 85 maka diambil sampel seluruh pegawai PT Pegadaian (Persero) Kanwil X Bandung sebagai perwakilannya.

DEFINISI OPERASIONAL VARIABEL

Secara lebih rinci operasional variabel dalam penelitian ini dapat dilihat pada tabel berikut:
Tabel 1 Operasional Variabel Penelitian

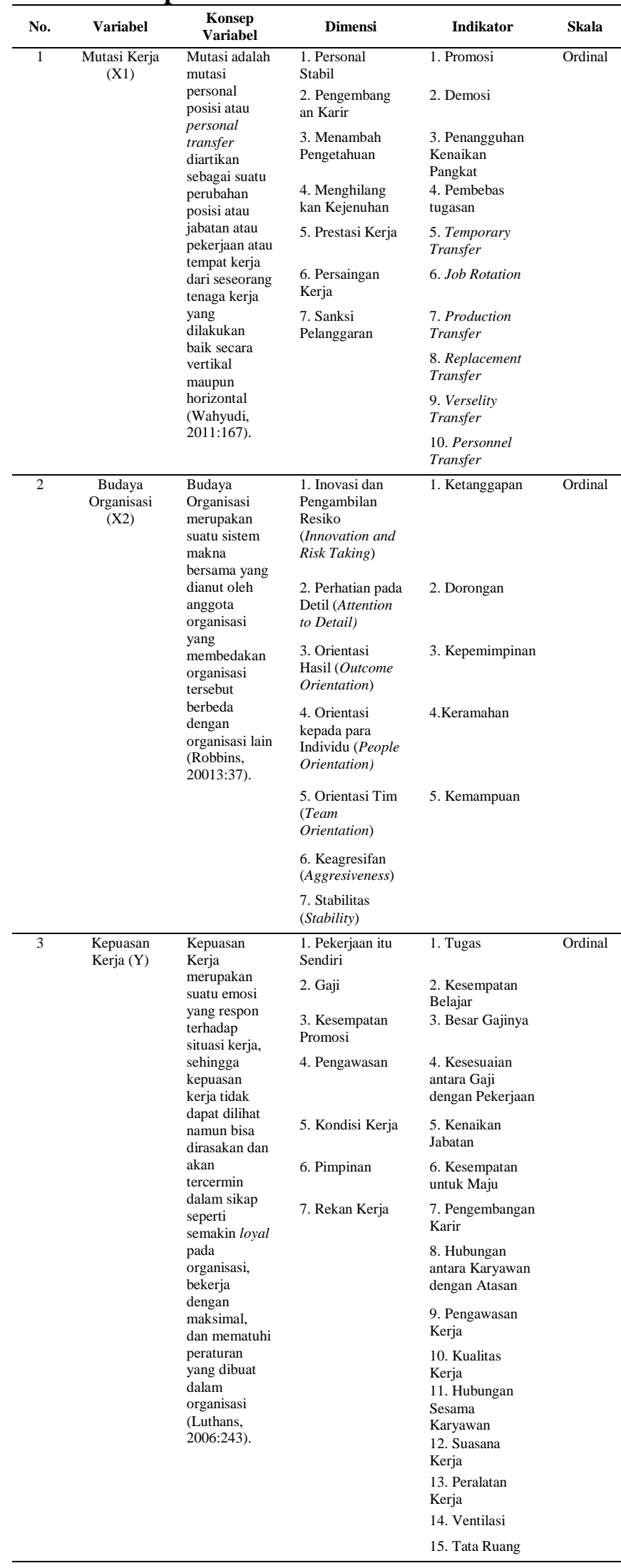

\section{METODE ANALIS DATA}

Metode analisis data yang digunakan dalam penelitian ini yaitu model regresi berganda yaitu 
metode statistik untuk menguji hubungan antara satu variabel terikat dan satu atau lebih variabel bebas (Ghozali, 2009:125). Dalam penelitian ini metode regresi berganda digunakan untuk melihat pengaruh variabel bebas (independent variable) yaitu Mutasi (X1) dan Budaya Organisasi (X2) terhadap variabel terikat (dependent variable) yaitu Kepuasan Kerja (Y). Sehingga dalam penelitian ini model persamaan regresi linear bergandanya sebagai berikut:

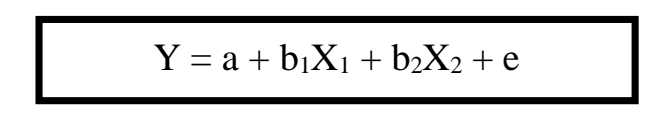

\begin{tabular}{|c|c|c|c|c|c|c|}
\hline \multicolumn{7}{|c|}{ Coefficients $^{\mathrm{a}}$} \\
\hline \multirow[t]{2}{*}{ Mode } & & \multicolumn{2}{|c|}{$\begin{array}{l}\text { Unstandardized } \\
\text { Coefficients }\end{array}$} & \multirow{2}{*}{$\begin{array}{c}\begin{array}{c}\text { Standard } \\
\text { ized } \\
\text { Coeffici } \\
\text { ents }\end{array} \\
\text { Beta }\end{array}$} & \multirow[t]{2}{*}{$\mathrm{t}$} & \multirow[t]{2}{*}{ Sig. } \\
\hline & & B & $\begin{array}{l}\text { Std. } \\
\text { Error }\end{array}$ & & & \\
\hline \multirow{3}{*}{1} & (Constant) & 3.691 & 5.94 & & 0.621 & 0.536 \\
\hline & Mutasi & 0.407 & 0.157 & 0.221 & 2.597 & 0.011 \\
\hline & $\begin{array}{l}\text { Budaya } \\
\text { Organisasi }\end{array}$ & 0.908 & 0.128 & 0.606 & 7.113 & 0 \\
\hline
\end{tabular}

Sumber: Data yang telah diolah (2018)

Berdasarkan tabel di atas, dapat diperoleh persamaan regresi sebagai berikut:

$\mathrm{Y}=3.691+0.407 \mathrm{X} 1+0.908 \mathrm{X} 2+\mathrm{e}$

dimana:

$\mathrm{a}=3.691$ artinya jika mutasi dan budaya organisasi sama dengan nol, maka kepuasan kerja sama dengan 3.691.

b1 $=0.407$ artinya jika variabel mutasi meningkat sebesar satu satuan, maka kepuasan kerja meningkat sebesar 0.407 .

b2 $=0.908$ artinya jika variabel budaya organisasi meningkat sebesar satu satuan, maka kepuasan kerja meningkat sebesar 0.908.

$$
\begin{array}{ll}
\mathrm{Y} & =\text { Kepuasan Kerja } \\
\mathrm{X} 1 & =\text { Mutasi } \\
\mathrm{X} 2 & =\text { Budaya Organisasi } \\
\mathrm{e} & =\text { error }
\end{array}
$$

Sedangkan apabila berdasarkan hasil kuesioner yang disebarkan kepada responden, maka dapat diketahui pernyataan responden setiap jawaban diberi nilai berdasarkan skala likert. Adapun kriteria penilaian sebagai berikut:

$\begin{array}{ll}\text { Sangat Setuju (SS) } & =5 \\ \text { Setuju (S) } & =4 \\ \text { Netral (N) } & =3 \\ \text { Tidak Setuju (TS) } & =2 \\ \text { Sangat Tidak Setuju (STS) } & =1\end{array}$

Selanjutnya dicari rata-rata setiap jawaban responden, untuk memudahkan penilaian dari rata-rata tersebut, maka digunakan interval untuk menentukan panjang kelas interval, maka digunakan rumus menurut Sudjana \& Ibrahim (2012:79) sebagai berikut:

$$
\mathbf{P}=\frac{\text { Rentang }}{\text { Banyak Kelas }}
$$

Di mana:

$$
\begin{array}{ll}
\mathrm{P} & =\text { Panjang kelas interval } \\
\text { Rentang } & =\text { Data terbesar }- \text { data terkecil } \\
\text { Banyak kelas } & =5
\end{array}
$$

Berdasarkan rumus, maka panjang kelas interval adalah:

$$
\begin{aligned}
P & =\frac{5-1}{5} \\
& =0.80
\end{aligned}
$$

Maka interval dari kriteria penilaian rata-rata dapat diinterpretasikan sebagai berikut:

$$
\begin{array}{ll}
\text { Sangat Tidak Baik } & =1.00-1.79 \\
\text { Tidak Baik } & =1.80-2.59 \\
\text { Cukup } & =2.60-3.39 \\
\text { Baik } & =3.40-4.19 \\
\text { Sangat Baik } & =4.20-5.00
\end{array}
$$

\section{HASIL DAN PEMBAHASAN}

Uji Instrumen Penelitian (Uji Validitas dan Uji Reliabilitas)

Sebuah instrumen dikatakan valid apabila instrumen itu mampu mengukur apa yang diinginkan dan dapat mengukur data dari variabel yang diteliti secara tepat. Tinggi rendahnya validitas instrumen menunjukkan sejauh mana data terkumpul tidak menyimpang dari gambaran 
tentang variabel yang dimaksud. Menurut Sugiyono (2014:172), valid berarti instrumen yang digunakan dapat mengukur apa yang seharusnya diukur. Uji validitas dimaksudkan untuk mendapatkan butir-butir pertanyaan yang benar-benar tepat yaitu yang dapat mengungkapkan tingkat validitas. Suatu instrumen yang dinyatakan valid jika mampu mengukur apa yang diinginkan dan dapat diungkapkan data dan variabel yang diteliti secara tepat. Suatu kuesioner dikatakan valid jika pertanyaan pada kuesioner mampu untuk mengungkapkan sesuatu yang akan diukur oleh kuesioner tersebut. Uji validitas dalam penelitian ini dilakukan dengan menggunakan validitas konstruk. Item-item dalam kuesioner dapat dikatakan valid bila korelasi tiap faktornya bernilai positif dan besarnya > 0.3 (Sugiyono, 2014:38). Berdasarkan pengujian validitas dengan menggunakan SPSS 21 dapat ditentukan validitas kuesioner-kuesioner dari variabel peneltian yang diteliti. Berikut hasil uji validitas dalam penelitian ini:

Tabel 3 Hasil Uji Validitas

\begin{tabular}{|c|c|c|c|c|}
\hline & \multicolumn{3}{|c|}{ Pearson Correlation } & \multirow[b]{2}{*}{ Keterangan } \\
\hline & $\begin{array}{c}\text { Total_ } \\
\mathbf{M}^{-}\end{array}$ & $\begin{array}{c}\text { Total } \\
\text { BO }\end{array}$ & $\begin{array}{c}\text { Total_ } \\
\text { KK }\end{array}$ & \\
\hline M1 & 0.446 & & & Valid \\
\hline M2 & 0.01 & & & Tidak Valid \\
\hline M3 & 0.434 & & & Valid \\
\hline M4 & 0.425 & & & Valid \\
\hline M5 & 0.546 & & & Valid \\
\hline M6 & 0.591 & & & Valid \\
\hline M7 & 0.424 & & & Valid \\
\hline M8 & 0.584 & & & Valid \\
\hline M9 & 0.573 & & & Valid \\
\hline M10 & 0.274 & & & Tidak Valid \\
\hline M11 & 0.679 & & & Valid \\
\hline M12 & 0.079 & & & Tidak Valid \\
\hline M13 & 0.432 & & & Valid \\
\hline M14 & 0.291 & & & Tidak Valid \\
\hline BO1 & & 0.425 & & Valid \\
\hline $\mathrm{BO} 2$ & & 0.477 & & Valid \\
\hline $\mathrm{BO} 3$ & & 0.714 & & Valid \\
\hline $\mathrm{BO} 4$ & & 0.559 & & Valid \\
\hline BO5 & & -0.072 & & Tidak Valid \\
\hline BO6 & & 0.771 & & Valid \\
\hline BO7 & & 0.471 & & Valid \\
\hline BO8 & & 0.549 & & Valid \\
\hline BO9 & & 0.664 & & Valid \\
\hline
\end{tabular}

\begin{tabular}{lccc} 
BO10 & 0.695 & & Valid \\
BO11 & 0.684 & & Valid \\
BO12 & 0.77 & & Valid \\
BO13 & 0.556 & & Valid \\
BO14 & 0.479 & & Valid \\
\hline KK1 & & 0.555 & Valid \\
KK2 & 0.617 & Valid \\
KK3 & 0.658 & Valid \\
KK4 & 0.657 & Valid \\
KK5 & & 0.644 & Valid \\
KK6 & 0.762 & Valid \\
KK7 & & 0.687 & Valid \\
KK8 & 0.738 & Valid \\
KK9 & & 0.418 & Valid \\
KK10 & & 0.273 & Tidak Valid \\
KK11 & & Valid \\
KK12 & & 0.786 & Valid \\
KK13 & 0.73 & Valid \\
KK14 & & Valid \\
KK15 & & 0.723 & Valid \\
KK16 & 0.707 & Valid \\
KK17 & & 0.725 & Valid \\
KK18 & & 0.764 & telah diolah 2018$)$
\end{tabular}

Berdasarkan Tabel 3 Hasil Uji Validitas terlihat bahwa M, BO, dan KK menunjukkan hasil yang signifikan yaitu nilai pearson correlation > 0.3 kecuali item M2, M10, M12, M14, BO5, dan KK10 memiliki nilai pearson correlation lebih kecil dari 0.3. Jadi dapat disimpulkan bahwa seluruh item $\mathrm{BO}, \mathrm{K}$, dan TI adalah valid kecuali M2, M10, M12, M14, BO5, dan KK10 maka dari itu item tersebut harus dibuang.

Uji reliabilitas dilakukan untuk mengetahui tingkat konsistensi hasil pengukuran bila dilakukan pengukuran ulang terhadap gejala dan alat ukur yang sama. Reliabilitas berarti menunjukkan pada tingkat keterandalan sesuatu. Reliable artinya terpercaya, dapat dipercaya, jadi dapat diandalkan. Instrumen yang reliabel adalah instrumen yang bila digunakan beberapa kali untuk mengukur obyek yang sama, akan menghasilkan data yang sama (Sugiyono, 2014:173). Sedangkan menurut Indriantoro dan Supomo (2014:180), bahwa konsep reliabilitas dapat dipahami melalui ide dasar konsep tersebut yaitu konsistensi. Formula statistik yang dapat digunakan untuk menguji reliabilitas adalah Alpha Cronbach. Uji reliabilitas dimaksudkan untuk mengukur suatu kuesioner yang merupakan 
indikator dari variabel. Reliabilitas diukur dengan uji statistik cronbach alpha dan dikatakan reliabel jika memberikan nilai alpha $>0.60$. Berikut hasil pengujian reliabilitas dalam penelitian ini:

Tabel 4 Hasil Koefisien Reliabilitas

\begin{tabular}{ccc}
\hline Variabel & $\begin{array}{c}\text { Cronbach's } \\
\text { Alpha }\end{array}$ & Keterangan \\
\hline M & 0.739 & Reliabel \\
BO & 0.85 & Reliabel \\
KK & 0.921 & Reliabel \\
\hline
\end{tabular}

Sumber: Data yang telah diolah (2018)

Dari hasil uji reliabilitas di atas seluruh variabel yang telah dinyatakan valid juga dinyatakan reliabel. Adapun batasan kriteria reliabilitas adalah 0.60 Seluruh variabel tersebut memenuhi kriteria, yaitu Cornbach's Alpha lebih besar atau sama dengan 0.60. Kemudian didapatkan hasil yang menunjukkan bahwa keseluruhan item reliabel. Dengan demikian penelitian ini dapat dilanjutkan.

\section{Analisis Statistik Penelitian}

\section{Uji Normalitas}

Uji normalitas bertujuan untuk menguji apakah dalam sebuah model regresi, variabel dependen dan independen memiliki distribusi yang normal atau tidak. Distribusi data yang normal atau mendekati normal merupakan model regresi yang baik. Data dengan distribusi yang normal dapat dikatakan mempunyai sebaran yang normal pula, oleh sebab itu dengan data seperti ini maka data dapat dianggap mewakili populasi. Uji normalitas pada dasarnya melakukan perbandingan antara data yang kita miliki dengan data berdistribusi normal yang memiliki mean dan standar deviasi yang sama dengan data. Menurut Sugiyono (2014:5), uji normalitas memiliki kriteria sebagai berikut:

- Jika angka signifikansi (Sig) $\geq \alpha=0.05$, maka data berdistribusi normal.

- Jika angka signifikansi (Sig) $<\alpha=0.05$, maka data berdistribusi tidak normal.

\section{Tabel 5 Hasil Uji Normalitas}

One-Sample Kolmogorov Smirnov Test

\begin{tabular}{|c|c|c|}
\hline & & $\begin{array}{c}\text { Unstandardized } \\
\text { Residual }\end{array}$ \\
\hline \multirow[t]{2}{*}{$\mathrm{N}$} & & 85 \\
\hline & Mean & .0000000 \\
\hline Normal Parameters ${ }^{\mathrm{a}, \mathrm{b}}$ & $\begin{array}{l}\text { Std. } \\
\text { Deviation }\end{array}$ & 630.189 .481 \\
\hline
\end{tabular}

\begin{tabular}{llr} 
& Absolute & .081 \\
Most Extreme & Positive & .045 \\
Differences & Negative & -.081 \\
& .747 \\
Kolmogorov-Smirnov Z & .632 \\
Asymp. Sig. (2-tailed) & \\
\hline a. Test distribution is Normal. & \\
b. Calculated from data. & \\
\multicolumn{2}{l}{ Sumber: Data yang telah diolah (2018) }
\end{tabular}

Hasil uji normalitas pada tabel di atas menunjukkan bahwa nilai asymp sig yang diperoleh sebesar 0.632. Nilai ini lebih besar dibandingkan tingkat signifikansi yang digunakan yaitu 0.05 . Berdasarkan kriteria uji normalitas, dapat disimpulkan bahwa artinya data residual berdistribusi normal.

2. Uji Multikolinearitas

Uji multikolinearitas bertujuan untuk menguji apakah model regresi ditemukan adanya kolerasi antar variabel independen (Ghozali, 2009:88). Model regresi yang baik seharusnya tidak terjadi kolerasi di antara variabel independen. Untuk mendeteksi ada atau tidaknya multikolinearitas pada model regresi dapat dilakukan dengan melihat nilai tolerance dan nilai Variance Inflation Factor dengan hipotesis pengujian:

$\mathrm{H}_{0}$ : Tidak ada multikolinearitas

$\mathrm{H}_{1}$ : Ada multikolinearitas

Kriteria penerimaan/penolakan:

Apabila tolerance $\geq 0.1$ dan VIF $\leq 10 \rightarrow$

$\mathrm{H}_{0}$ diterima

Apabila tolerance $<0.1$ dan VIF $>10 \rightarrow$ $\mathrm{H}_{0}$ ditolak

Tabel 6 Hasil Uji Multikolinearitas

\begin{tabular}{|c|c|c|c|c|c|c|c|c|}
\hline \multicolumn{9}{|c|}{ Coefficients $^{a}$} \\
\hline \multirow[t]{2}{*}{ Mo } & & \multicolumn{2}{|c|}{$\begin{array}{l}\text { Unstandardized } \\
\text { Coefficients }\end{array}$} & \multirow{2}{*}{$\begin{array}{c}\begin{array}{c}\text { Standardize } \\
\mathrm{d} \\
\text { Coefficients }\end{array} \\
\text { Beta }\end{array}$} & \multirow{2}{*}{ t } & \multirow{2}{*}{ Sig. } & \multicolumn{2}{|c|}{$\begin{array}{l}\text { Collinearity } \\
\text { Statistics }\end{array}$} \\
\hline & & B & $\begin{array}{l}\text { Std. } \\
\text { Error }\end{array}$ & & & & $\begin{array}{c}\text { Toleranc } \\
\mathrm{e}\end{array}$ & VIF \\
\hline \multirow{3}{*}{1} & (Constant & $\begin{array}{r}3.69 \\
1\end{array}$ & $\begin{array}{r}5.94 \\
0\end{array}$ & & .621 & $\begin{array}{r}.53 \\
6\end{array}$ & & \\
\hline & Mutasi & . 407 & .157 & .221 & $\begin{array}{r}2.59 \\
7\end{array}$ & $\begin{array}{r}.01 \\
1\end{array}$ & .757 & $\begin{array}{r}1.32 \\
2\end{array}$ \\
\hline & $\begin{array}{l}\text { Budaya } \\
\text { Organisas } \\
\mathrm{i}\end{array}$ & .908 & .128 & .606 & $\begin{array}{r}7.11 \\
3\end{array}$ & $\begin{array}{r}.00 \\
0\end{array}$ & .757 & $\begin{array}{r}1.32 \\
2\end{array}$ \\
\hline
\end{tabular}

Sumber: Data yang telah diolah (2018)

Tabel di atas menunjukkan bahwa variabel $\mathrm{BO}$ dan K memiliki nilai tolerance lebih besar dari 0.1 dan nilai VIF lebih kecil dari 10, sehingga dapat disimpulkan bahwa tidak ada multikolinearitas dalam model regresi.

\section{Uji Heterokedastisitas}


Uji heteroskedastisitas bertujuan menguji apakah dalam model regresi terjadi ketidaksamaan variance dari residual satu pengamatan ke pengamatan lain (Ghozali, 2009:125). Cara untuk mendeteksi ada atau tidaknya heteroskedastisitas melalui melihat Grafik Plot antara nilai prediksi variabel terikat (dependen) yaitu ZPRED dengan residualnya SRESID. Deteksi ada tidaknya heteroskedastisitas dapat dilakukan dengan melihat ada tidaknya pola tertentu pada grafik scatterplot antara SRESID dan ZPRED di mana sumbu $\mathrm{Y}$ adalah $\mathrm{Y}$ yang telah diprediksi, dan sumbu $\mathrm{X}$ adalah residual ( $\mathrm{Y}$ prediksi $-\mathrm{Y}$ sesungguhnya) yang telah di-studentized. Dari grafik scatterplots terlihat bahwa titik-titik menyebar secara acak serta tersebar baik di atas maupun di bawah angka 0 pada sumbu Y. Hal ini dapat disimpulkan bahwa tidak terjadi heteroskedastisitas pada model regresi, sehingga model regresi layak untuk dipakai (Ghozali, 2009:125).

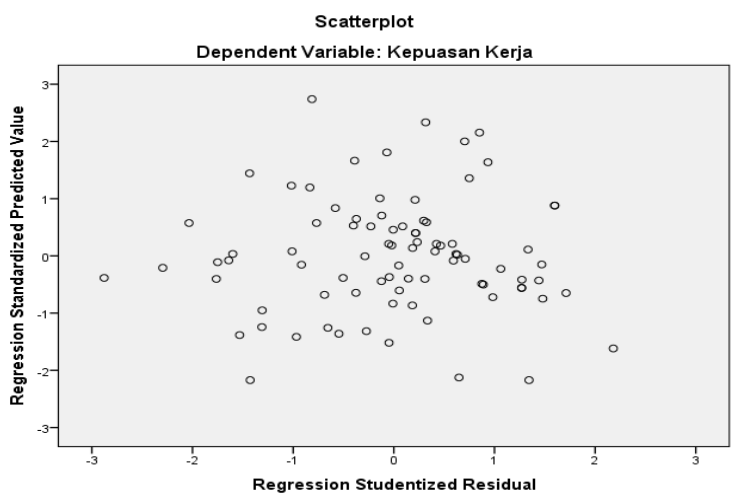

Gambar 3 Scatterplot

Sumber: Data yang telah diolah (2018)

4. Uji Regresi Linier Berganda/ Analisis Data Metode analisis data yang digunakan dalam penelitian ini yaitu model regresi berganda yaitu metode statistik untuk menguji hubungan antara satu variabel terikat dan satu atau lebih variabel bebas (Ghozali, 2009:125). Dalam penelitian ini metode regresi berganda digunakan untuk melihat pengaruh variabel bebas (independent variable) yaitu Mutasi (X1) dan Budaya Organisasi (X2) terhadap variabel terikat (dependent variable) yaitu Kepuasan Kerja (Y). Sehingga dalam penelitian ini model persamaan regresi linear bergandanya sebagai berikut:

$$
\mathrm{Y}=\mathrm{a}+\mathrm{b}_{1} \mathrm{X}_{1}+\mathrm{b}_{2} \mathrm{X}_{2}+\mathrm{e}
$$

Tabel 7 Coefficients Regresi Linier Berganda

\begin{tabular}{|c|c|c|c|c|c|c|}
\hline \multicolumn{7}{|c|}{ Coefficients $^{\mathrm{a}}$} \\
\hline \multirow{2}{*}{ Model } & & \multicolumn{2}{|c|}{$\begin{array}{l}\text { Unstandardized } \\
\text { Coefficients }\end{array}$} & \multirow{2}{*}{$\begin{array}{c}\begin{array}{c}\text { Standardized } \\
\text { Coefficients }\end{array} \\
\text { Beta }\end{array}$} & \multirow{2}{*}{$\mathrm{t}$} & \multirow{2}{*}{ Sig. } \\
\hline & & B & $\begin{array}{c}\text { Std. } \\
\text { Error }\end{array}$ & & & \\
\hline \multirow{3}{*}{1} & (Constant) & 3.691 & 5.940 & & .621 & .536 \\
\hline & Mutasi & .407 & .157 & .221 & 2.597 & .011 \\
\hline & $\begin{array}{l}\text { Budaya } \\
\text { Organisasi }\end{array}$ & .908 & .128 & .606 & 7.113 & .000 \\
\hline
\end{tabular}

Sumber: Data yang telah diolah (2018)

Berdasarkan tabel di atas, dapat diperoleh persamaan regresi sebagai berikut:

$\mathrm{Y}=3.691+0.407 \mathrm{X} 1+0.908 \mathrm{X} 2+\mathrm{e}$

dimana:

$\mathrm{a}=3.691$ artinya jika mutasi dan budaya organisasi sama dengan nol, maka kepuasan kerja sama dengan 3.691.

b1 $=0.407$ artinya jika variabel mutasi meningkat sebesar satu satuan, maka kepuasan kerja meningkat sebesar 0.407 .

b2 $=0.908$ artinya jika variabel budaya organisasi meningkat sebesar satu satuan, maka kepuasan kerja meningkat sebesar 0.908 .

$\mathrm{Y} \quad=$ Kepuasan Kerja

$\mathrm{X} 1=$ Mutasi

$\mathrm{X} 2=$ Budaya Organisasi

$\mathrm{e} \quad=$ error

\section{Uji Hipotesis Penelitian}

a. Uji T (Uji Hipotesis secara Parsial antara Variabel Mutasi dan Budaya Organisasi terhadap Kepuasan Kerja di Lingkungan PT Pegadaian (PERSERO))

Uji t atau uji parsial digunakan untuk mengetahui pengaruh masing-masing variabel independen terhadap variabel dependen (Ghozali, 2009:88). Hipotesis yang diuji adalah:

$\mathrm{H}_{0}$ : Tidak ada pengaruh variabel independen terhadap variabel dependen

$\mathrm{H}_{1}$ : Ada pengaruh variabel independen terhadap variabel dependen

Kriteria penerimaan/penolakan:

Asymp sig $>0.05 \rightarrow \mathrm{H}_{0}$ diterima

Asymp sig $\leq 0.05 \rightarrow \mathrm{H}_{0}$ ditolak

Tabel 8 Coefficients Uji t Regresi Linier Berganda

\begin{tabular}{llllll}
\multicolumn{8}{c}{ Coefficients $^{\mathbf{a}}$} & & & \\
\hline \multirow{3}{*}{ Model } & \multicolumn{2}{c}{$\begin{array}{l}\text { Unstandardized } \\
\text { Coefficients }\end{array}$} & $\begin{array}{c}\text { Standardized } \\
\text { Coefficients }\end{array}$ & t & Sig. \\
\cline { 2 - 4 } & B & $\begin{array}{c}\text { Std. } \\
\text { Error }\end{array}$ & Beta & & \\
\hline
\end{tabular}




\begin{tabular}{rlrrrrr} 
& (Constant) & 3.691 & 5.940 & & .621 & .536 \\
1 & Mutasi & .407 & .157 & .221 & 2.597 & .011 \\
& $\begin{array}{l}\text { Budaya } \\
\text { Organisasi }\end{array}$ & .908 & .128 & .606 & 7.113 & .000 \\
\hline
\end{tabular}

a. Dependent Variable: Kepuasan Kerja

Sumber: Data yang telah diolah (2018)

Dari hasil uji statistik pada Tabel 8, maka dapat disimpulkan bahwa variabel mutasi dari hasil uji di atas memiliki nilai Sig sebesar 0.011 lebih kecil dari 0.05 , artinya $\mathrm{H}_{0}$ ditolak sehingga dapat disimpulkan bahwa variabel mutasi memiliki pengaruh terhadap kepuasan kerja serta variabel budaya organisasi dari hasil uji di atas memiliki nilai Sig sebesar 0.000 lebih kecil dari 0.05, artinya $\mathrm{H}_{0}$ ditolak sehingga dapat disimpulkan bahwa variabel budaya organisasi memiliki pengaruh terhadap kepuasan kerja.

b. Uji F (Uji Hipotesis secara Simultan antara Variabel Mutasi dan Budaya Organisasi terhadap Kepuasan Kerja di Lingkungan PT. Pegadaian (PERSERO))

Uji $F$ digunakan untuk mengetahui tingkat signifikansi pengaruh variabel-variabel independen secara bersama-sama (simultan) terhadap variabel dependen. Selain itu, hipotesis kemudian diuji untuk mengetahui diterima atau ditolak hipotesis. Pengujian hipotesis ditunjukan untuk menguji ada tidaknya pegaruh dari variabel bebas secara keseluruhan terhadap variabel dependen. Hipotesis yang diuji adalah:

$\mathrm{H}_{0}$ : Tidak ada pengaruh variabel independen secara simultan terhadap variabel dependen

$\mathrm{H}_{1}$ : Ada pengaruh variabel independen secara simultan terhadap variabel dependen

Kriteria penerimaan/penolakan:

Asymp sig $>0.05 \rightarrow \mathrm{H}_{0}$ diterima

Asymp sig $\leq 0.05 \rightarrow \mathrm{H}_{0}$ ditolak

Tabel 9 ANOVA Regresi Linier Berganda

\begin{tabular}{|c|c|c|c|c|c|c|}
\hline \multicolumn{7}{|c|}{ ANOVA $^{a}$} \\
\hline Model & & $\begin{array}{l}\text { Sum of } \\
\text { Squares }\end{array}$ & df & $\begin{array}{l}\text { Mean } \\
\text { Square }\end{array}$ & F & Sig. \\
\hline \multirow{3}{*}{1} & Regression & 4.062 .340 & 2 & 2.031 .170 & 49.927 & $.000^{\mathrm{b}}$ \\
\hline & Residual & 3.335 .966 & 82 & 40.683 & & \\
\hline & Total & 7.398 .306 & 84 & & & \\
\hline
\end{tabular}

a. Dependent Variable: Kepuasan Kerja

b. Predictors: (Constant), Budaya Organisasi, Mutasi

Sumber: Data yang telah diolah (2018)

Hasil pengolahan regresi variabel mutasi dan budaya organisasi terhadap kepuasan kerja dapat dilihat pada Tabel 7. Sedangkan berdasarkan Tabel 9 ANOVA, nilai Sig. yang diperoleh adalah sebesar 0.000. Nilai ini lebih kecil dibandingkan tingkat signifikasi yang digunakan yaitu 0.05 , artinya $\mathrm{H}_{0}$ ditolak sehingga dapat disimpulkan bahwa secara bersama-sama atau secara simultan variabel mutasi dan budaya organisasi berpengaruh terhadap kepuasan kerja.

\section{c. Uji Koefisien Determinasi}

Untuk mengetahui seberapa besar pengaruh mutasi dan budaya organisasi (variabel $\mathrm{X}$ ) terhadap kepuasan kerja (variabel Y), maka menurut Sugiyono (2013:6), dapat dilakukan analisis koefisien determinasi (Kd) sebagai berikut:

$\mathrm{Kd}=\mathrm{r}^{2} \times 100 \%$

keterangan:

$\mathrm{Kd}=$ Koefisien determinasi

$\mathrm{r}=$ Koefisien korelasi

Tabel 10 Model Summary

Model Summary

\begin{tabular}{|c|c|c|c|c|c|}
\hline Model & & $\mathrm{R}$ & $\begin{array}{c}\mathrm{R} \\
\text { Square }\end{array}$ & $\begin{array}{c}\text { Adjusted R } \\
\text { Square }\end{array}$ & $\begin{array}{l}\text { Std. Error } \\
\text { of the } \\
\text { Estimate }\end{array}$ \\
\hline & 1 & $.741^{\mathrm{a}}$ & .549 & .538 & 637.828 \\
\hline
\end{tabular}

a. Predictors: (Constant), Budaya Organisasi, Mutasi

Sumber: Data yang telah diolah (2018)

\section{d. Tingkat Pengaruh Mutasi Secara Parsial Terhadap Kepuasan Kerja di Lingkungan PT Pegadaian (PERSERO)}

Besaran nilai pengaruh yang dihasilkan variabel mutasi terhadap kepuasan kerja dalam hal ini dapat diperoleh melalui tabel correlation berikut dengan menghitung nilai koefisien determinasinya. Berikut hasil besar pengaruh secara parsial:

Tabel 11 Correlations Regresi Linier Berganda

\begin{tabular}{|c|c|c|c|c|}
\hline \multicolumn{5}{|c|}{ Correlations } \\
\hline & & $\begin{array}{c}\text { Kepuasan } \\
\text { Kerja }\end{array}$ & Mutasi & $\begin{array}{c}\text { Budaya } \\
\text { Organisasi }\end{array}$ \\
\hline \multirow{3}{*}{$\begin{array}{l}\text { Pearson } \\
\text { Correlation }\end{array}$} & $\begin{array}{l}\text { Kepuasan } \\
\text { Kerja }\end{array}$ & 1.000 & .520 & .716 \\
\hline & Mutasi & .520 & 1.000 & .493 \\
\hline & $\begin{array}{l}\text { Budaya } \\
\text { Organisasi }\end{array}$ & .716 & .493 & 1.000 \\
\hline \multirow{3}{*}{ Sig. (1-tailed) } & $\begin{array}{l}\text { Kepuasan } \\
\text { Kerja }\end{array}$ & . & .000 & .000 \\
\hline & Mutasi & .000 & . & .000 \\
\hline & $\begin{array}{l}\text { Budaya } \\
\text { Organisasi }\end{array}$ & .000 & .000 & . \\
\hline \multirow{3}{*}{$\mathrm{N}$} & $\begin{array}{l}\text { Kepuasan } \\
\text { Kerja }\end{array}$ & 85 & 85 & 85 \\
\hline & Mutasi & 85 & 85 & 85 \\
\hline & $\begin{array}{l}\text { Budaya } \\
\text { Organisasi }\end{array}$ & 85 & 85 & 85 \\
\hline
\end{tabular}

Sumber: Data yang telah diolah (2018) 
Berdasarkan tabel correlation dapat diketahui besarnya pengaruh secara parsial. Besarnya pengaruh secara parsial dari variabel mutasi terhadap kepuasan kerja dengan nilai koefisien determinasi:

$\mathrm{Kd}=\mathrm{r}^{2} \times 100 \%$

$\mathrm{Kd}=0.520^{2} \times 100 \%=27.04 \%$. Artinya, dimana variabel mutasi berpengaruh secara parsial terhadap kepuasan kerja dengan tingkat persentase sebesar $27.04 \%$.

\section{e. Tingkat Pengaruh Budaya Organisasi} Secara Parsial Terhadap Kepuasan Kerja di Lingkungan PT Pegadaian (PERSERO)

Sedangkan untuk besarnya pengaruh secara parsial variabel budaya organisasi terhadap kepuasan kerja dapat dilihat di Tabel 11 dan kemudian dihitung dengan nilai koefisien determinasi:

$\mathrm{Kd}=\mathrm{r}^{2} \times 100 \%$

$\mathrm{Kd}=0.716^{2} \times 100 \%=51.27 \%$. Artinya, dimana variabel budaya organisasi berpengaruh secara parsial terhadap kepuasan kerja dengan tingkat persentase sebesar $51.27 \%$.

f. Tingkat Pengaruh Mutasi dan Budaya Organisasi Secara Simultan Terhadap Kepuasan Kerja di Lingkungan PT Pegadaian (PERSERO)

Berdasarkan tabel model summary sebelumnya dapat diketahui besarnya pengaruh secara simultan mutasi dan budaya organisasi secara bersama-sama terhadap kepuasan kerja di lingkungan kerja PT Pegadaian (PERSERO). Besarnya pengaruh secara simultan atau secara bersama-sama dapat dilihat pada Tabel 10, pada tabel Model Summary kolom Adjusted R Square dengan persentase sebesar $53.8 \%$.

\section{KESIMPULAN}

1. Pengaruh mutasi secara parsial terhadap kepuasan kerja memiliki nilai Sig. sebesar 0.011 lebih kecil dari 0.05 , artinya $\mathrm{H}_{\mathrm{o}}$ ditolak sehingga dapat disimpulkan bahwa variabel mutasi memiliki pengaruh terhadap kepuasan kerja di lingkungan PT Pegadaian (Persero) Kanwil X Bandung sebesar $1.1 \%$. Serta apabila berdasarkan hasil tanggapan responden secara keseluruhan untuk pertanyaan dalam variabel mutasi, dapat diketahui bahwa variabel mutasi memiliki nilai rata-rata sebesar 3.56 berarti variabel mutasi $\left(\mathrm{X}_{1}\right)$ berada pada kategori baik. Dalam hal ini variabel mutasi memiliki pengaruh namun dalam persentase kecil yang dimana dapat digunakan sebagai bahan pengkajian bagi perusahaan.
2. Pengaruh budaya organisasi secara parsial terhadap kepuasan kerja memiliki nilai Sig. sebesar 0.000 lebih kecil dari 0.05 , artinya $\mathrm{H}_{\mathrm{o}}$ ditolak sehingga dapat disimpulkan bahwa variabel budaya organisasi berpengaruh terhadap kepuasan kerja di lingkungan PT Pegadaian (Persero) Kanwil X Bandung tetapi tidak memiliki nilai persentase atau sebesar $0 \%$. Serta apabila berdasarkan hasil tanggapan responden secara keseluruhan untuk pertanyaan dalam variabel budaya organisasi, dapat diketahui bahwa variabel budaya organisasi memiliki nilai rata-rata sebesar 4.08 berarti variabel budaya organisasi $\left(\mathrm{X}_{2}\right)$ berada pada kategori baik. Dalam hal ini variabel budaya organisasi tidak menampilkan hasil yang diinginkan dikarenakan sebagian besar responden merasa budaya organisasi yang sekarang ada di perusahaan dinilai cukup baik dan hanya sebagian kecil pegawai yang merasakan ketidak cocokan budaya organisasi, maka tidak dapat hasil ini disamaratakan untuk keseluruhan pegawai di perusahaan.

3. Pengaruh mutasi dan budaya organisasi secara simultan terhadap kepuasan kerja diketahui terdapat nilai Sig. yang diperoleh sebesar 0.000 di mana nilai ini lebih kecil dibandingkan tingkat signifikasi yang digunakan yaitu 0.05 , artinya $\mathrm{H}_{\mathrm{o}}$ ditolak sehingga dapat disimpulkan bahwa secara bersama-sama atau secara simultan variabel mutasi dan budaya organisasi berpengaruh terhadap kepuasan kerja di lingkungan PT Pegadaian (Persero) Kanwil X Bandung tetapi tidak memiliki nilai persentase atau sebesar $0 \%$. Serta apabila berdasarkan hasil tanggapan responden secara keseluruhan untuk pertanyaan dalam variabel kepuasan kerja, dapat diketahui bahwa variabel kepuasan kerja memiliki nilai rata-rata sebesar 3.67 berarti variabel kepuasan kerja (Y) berada pada kategori baik. Variabel mutasi dan budaya organisasi yang dihubungkan dengan variabel kepuasan kerja menciptakan nilai rata-rata dalam kategori baik dimana hasil ini dapat memberikan pengaruh yang dapat dipertimbangan untuk dipertahankan di perusahaan.

\section{SARAN}

1. Sebaiknya sistem pemutasian dilakukan berdasarkan hasil analisis dan pengkajian lebih dahulu mengenai kebutuhan pegawai di tiap cabang serta tingkatkan budaya organisasi melalui pertemuan-pertemuan seperti 
refreshing penaksir dan family gathering yang umumnya dilakukan satu tahun sekali menjadi satu tahun dua kali. Hal tersebut dapat menjadi jembatan pertemuan dan pengikatan rekan kerja secara tidak langsung yang tersebar luas di seluruh area dalam tiap kanwilnya, namun berpengaruh cukup besar tanpa disadari. Berdasarkan hasil penelitian permasalahan terbesar yang dihadapi bahwa pegawai sebenarnya peduli dengan adanya pemutasian namun menginginkan pemutasian tersebut dilakukan oleh perusahaan secara adil dan transparan yang tidak hanya berdasarkan atas asas kedekatan namun dikarenakan kualitas kerja juga perlu dijadikan pertimbangan.

2. Budaya organisasi yang baik adalah dengan tidak menimbulkan masalah profesionalisme yang berubah menjadi masalah pribadi dan berkembang di dalam perusahaan, adanya batasan dan juga saling menghargai antar rekan kerja dan juga pimpinan di perusahaan sangat dibutuhkan, saling membantu apabila pekerjaan dirasa menumpuk dan lambat tertangani, serta tidak membebankan pekerjaan yang banyak kepada pegawai di luar job desk nya dengan alasan yang memberikannya adalah seorang pimpinan di perusahaan. Dengan adanya tindakan tersebut, budaya organisasi yang baik serta terstruktur akan tercipta seiring dengan perlakuan dan tindakan pimpinan kepada para pegawainya.

3. Pegawai juga seharusnya mampu untuk mengembangkan kemampuan diri tanpa perlu menunggu arahan dari perusahaan dengan cara memperbanyak mengikuti pelatihan-pelatihan yang sekiranya dapat membantu meningkatkan kualitas hasil pekerjaan beserta kuantitasnya, memperbaiki mutu pekerjaan dari waktu ke waktu serta dapat memahami bagaimana aturan yang berlaku di perusahaan tempat pegawai itu bekerja dengan baik. Kepuasan kerja akan dapat dirasakan apabila para pegawai sudah merasa menikmati pekerjaan dan lingkungan kerja yang nyaman.

\section{KETERBATASAN PENELITIAN}

Adapun kekurangan dalam penelitian ini adalah di mana para pegawai yang mengisi kuesioner terlihat bimbang dalam memilih jawaban dikarenakan hampir setiap pilihan bisa memproyeksikan diri mereka sendiri walaupun dalam penelitian ini, identitas dari para responden dirahasiakan namun terkesan tidak bisa benarbenar terbuka dalam menjawab setiap pertanyaannya.

\section{REFERENSI}

Bangun, W. (2012). Manajemen Sumber Daya Manusia. Jakarta: Erlangga.

Danim, S. (2012). Motivasi Kepemimpinan dan Efektivitas Kelompok. Jakarta: Rineka Cipta.

Dessler, G. dan Huat, T.C. (2006). Human Resources Management: An Asian Perspective. New Jersey: Prentice Hall.

Ellyzar, N., Yunus, M., dan Amri. (2017). Pengaruh Mutasi Kerja, Beban Kerja, dan Konflik Interpersonal Terhadap Stress Kerja Serta Dampaknya Pada Kinerja Pegawai BPKP Perwakilan Provinsi Aceh. Jurnal Magister Manajemen. Fakultas Ekonomi dan Bisnis Unsyiah. Vol. 1. No. 1: Hal. 35-45.

Fadilah, N. Asri., Hakim, A., dan Siswidiyanto. (2010). Pengaruh Penempatan Pegawai Terhadap Kinerja. Jurnal Administrasi Publik (JAP). Vol. 1, No. 5: Hal. 847-852.

Ghozali, I. (2009). Aplikasi Analisis Multivariate dengan Program SPSS. Semarang: Penerbit Universitas Dipenogoro.

Gibson, J., Ivancevich, J.M., dan Donnelly J.H., Jr. (2010). Organisasi, Perilaku, Struktur, Proses, Edisi Ke-5. Jakarta: Erlangga. . (2011). Organisasi: Perilaku, Struktur, Proses, Jilid 2. Jakarta: Binarupa Aksara.

Gomes, F.C. (2005). Manajemen Sumber Daya Manusia. Yogyakarta: Andi Offset.

Handoko, T.H. (2012). Manajemen Personalia dan Sumber Daya Manusia. Yogyakarta: BPFE.

Hormati, T. (2016). Pengaruh Budaya Organisasi, Rotasi Pekerjaan Terhadap Motivasi Kerja dan Kinerja Pegawai. Jurnal EMBA. Vol. 4. No. 2: Hal. 298-31.

Indriantoro, N. dan Supomo, B. (2014). Metodologi Penelitian Bisnis untuk Akuntansi \& Manajemen. Yogyakarta: BPFE.

Judas, A. (2013). Mutasi dan Promosi Jabatan Pengaruhnya Terhadap Prestasi Kerja Pegawai pada Kanwil Ditjen Kekayaan Negara Suluttenggo dan Maluku Utara di Manado. Jurnal EMBA. Vol. 1, No. 4: Hal. 1219-1228.

Kasiram M. (2008). Metode Penelitian Kuantitatif-Kualitatif. Malang: UIN Malang Press.

Kerlinger. (2006). Asas-Asas Penelitian Behavioral. Yogyakarta: Gadjah Mada University Press. 
Luthans, F. (2006). Perilaku Organisasi, Edisi Sepuluh. PT. Andi. Yogyakarta.

Martoyo, S. (2007). Manajemen Sumber Daya Manusia. Yogyakarta: BPFE-Yogyakarta.

Mathis, R.L. dan Jackson, J.H. (2006). Human Resource Management: Manajemen Sumber Daya Manusia. Terjemahan Dian Angelia. Jakarta: Salemba Empat.

Nazir, M. (2005). Metode Penelitian. Jakarta: Ghalia Indonesia.

Nitisemito, S.A. (2012). Manajemen Suatu Dasar dan Pengantar. Jakarta: Arena Ilmu.

Panggabean, S.M. (2007). Manajemen Sumber Daya Manusia. Bogor: Ghalia Indonesia.

Paul, P. dan Meters, A.C. (2005). Administrasi Kepegawaian. Indonesia: Musanef.

Rivai, V. dan Basri. (2005). Performance Appraisal, Cetakan Pertama. Jakarta: PT. Raja Grafindo Persada.

Robbins, S.P. (2013). Perilaku Organisasi, Buku 2. Jakarta: Salemba Empat.

(2008). Manajemen Sumber Daya Manusia Untuk Perusahaan: Dari Teori ke Praktik. Jakarta: Raja Grafindo Persada.

Ruky, S.A. (2006). Sistem Manajemen Kinerja. Jakarta: PT. Gramedia Pustaka Utama.

Samsudin, S. (2010). Manajemen Sumber Daya Manusia. Bandung: CV. Pustaka Setia.

Santoso, S. (2007). Statistik Parametik. Jakarta: PT. Gramedia Pustaka Umum.

Sastrohadiwiryo, S. (2014). Manajemen Tenaga Kerja Indonesia. Pendekatan Administrasi dan Operasional. Jakarta:Bumi Aksara.

Sedarmayanti. (2011). Sumber Daya Manusia dan Produktivitas Kerja. Jakarta: Mandar Maju. (2011). Pengembangan Kepribadian Pegawai. Bandung: Mandar Maju.

(2011). Metodologi Penelitian. Bandung: Mandar Maju. . (2016). Manajemen SDM. Bandung: Refika Aditama.

(2017). Perencanaan dan Pengembangan Sumber Daya Manusia. Bandung: Refika Aditama.

Sekaran, U. (2014). Metodologi Penelitian Untuk Bisnis (Research Methods for Business), Buku I Edisi 4. Jakarta: Salemba Empat.

Siagian, P. (2013). Manajemen Sumber Daya Manusia. Jakarta: PT. Bumi Aksara.

Simamora, H. (2012). Manajemen Sumber Daya Manusia, Edisi 1. Yogyakarta: STIE YKPN Yogyakarta.

Sopiah. (2008). Perilaku Organisasi. Yogyakarta: Andi Offset.
Sudjana, N. dan Ibrahim. (2012). Penelitian dan Penilaian Pendidikan. Bandung: Sinar Baru Algesindo.

Sugiyono. (2017). Metode Penelitian Kuantitatif, Kualitatif, dan R\&D. Bandung: Alfabeta.

Sulistiyani, T.A. dan Rosidah. (2009). Manajemen Sumber Daya Manusia. Yogyakarta: Graha Ilmu.

Suriasumantri, S.J. (2005). Filsafat Ilmu Sebuah Pengantar Popular. Jakarta: Pustaka Sinar Harapan.

Sutrisno, E. (2009). Manajemen Sumber Daya Manusia, Edisi Pertama. Jakarta: Kencana Prenada Media Group. - (2014). Manajemen Sumber Daya Manusia, Cetakan Keenam. Jakarta: Pranada Media Group. - (2013). Manajemen Sumber Daya Manusia. Bandung: CV. Pustaka Setia.

Tika, P. (2006). Budaya Organisasi dan Peningkatan Kinerja Perusahaan, Cetakan Pertama. Jakarta: PT. Bumi Aksara.

Wahyudi, B. (2011). Manajemen Sumber Daya Manusia. Bandung: Sulita.

Wibowo, M., Musadieq, A.M., dan Nurtjahjono, E.G. (2014). Pengaruh Lingkungan Kerja Terhadap Kepuasan Kerja Karyawan. Jurnal Administrasi Bisnis (JAB). Vol. 16 No. 1.

Yuli, S.B.C. (2005). Manajemen Sumber Daya Manusia. Malang: UMM Press. 